Pak. J. Agri., Agril. Engg., Vet. Sci., 2021, 37 (2): 132-138

ISSN: 1023-1072 (Print), ISSN: 2663-7863 (Online)

https://doi.org/10.47432/2021.37.2.9

\title{
AVIAN ESCHERICHIA COLI INFECTION IN MEAT-TYPE CHICKEN: PREVALENCE AND PATHOLOGY
}

\author{
Q. A. Shah ${ }^{* 1}$, N. M. Soomro ${ }^{2}$, J. M. Shah ${ }^{3}$, M. A. Hussain ${ }^{1}$ and S. F. Syed ${ }^{1}$ \\ ${ }^{1}$ Faculty of Veterinary and Animal Sciences, Lasbela University of Agriculture, Water and \\ Marine Sciences, Uthal, Balochistan, Pakistan \\ ${ }^{2}$ Faculty of Veterinary Medicine, University of Poonch, Rawala Kot Azad Jammu and Kashmir \\ ${ }^{3}$ Shaheed Benazir Bhutto University of Veterinary and Animal Sciences, Sakrand, Pakistan
}

\begin{abstract}
Avian colibacillosis is considered the major bacterial disease in the poultry industry worldwide. This study was conducted to determine prevalence and pathology by avian pathogenic Escherichia coli (APEC) in broiler chicken. Various organs of affected broilers were checked for the E. coli infection. One hundred and forty commercial poultry farms were divided into seven age groups (A, B, C, D, E, F, and G). Group A ( $1^{\text {st }}$ week), B ( $2^{\text {nd }}$ week), C ( $3^{\text {rd }}$ week $), D\left(4^{\text {th }}\right.$ week $), E\left(5^{\text {th }}\right.$ week $), F\left(6^{\text {th }}\right.$ week $), G$ ( $7^{\text {th }}$ to $9^{\text {th }}$ week). Investigations were conducted from day 1 until the marketing of birds based on clinical findings. A total of $2491(23.71 \%$ of sick birds) dead birds were observed positive for $E$. coli infection. Three forms of infection were observed i.e. omphalitis, colisepticaemia, and colibacillosis at the rate of $1.55,17$ and $56.65 \%$, respectively. Omphalitis was confirmed by microbial culture and revealed in only groups A and B with 76.24 and 23.76 respectively. While, Colisepticaemia was observed at the rate of $3.11,6.74,20.18,29.63,19.16$, and 22.18 in groups B, C, D, E, F, and G respectively. Whereas Colibacillosis was noticed as $0.075,3.35,5.99,19.20,26.70,16.11$ and $28.55 \%$ in groups A, B, C, D, $\mathrm{E}, \mathrm{F}$, and $\mathrm{G}$ respectively. Petechiation of heart, kidney, and gizzard besides hemorrhagic enteritis, hemorrhagic tracheitis, and necrotic foci on the liver and caseous exudates in air sacs were the prime gross lesions noticed in colibacillosis. Microscopically, no lesion was observed in serosa, muscularis externa, and submucosa. However, loss of epithelial tissue and breaches in the mucosal layer of the small intestine were observed. Furthermore, characteristic pink and grayish colonies were observed in E. coli cultures on McConkey's and Blood agar respectively.
\end{abstract}

Keywords: broiler, Escherichia coli, infection, pathology, prevalence

\section{INTRODUCTION}

The poultry industry, as a source of animal proteins for a balanced human diet, occupies an important place in the sphere of food production. The results of this study indicated that colibacillosis is highly prevalent in the study area; these observations raise serious concern and prompt attention and thus a huge economic could be reduced significantly and problematic aspects (i.e. under feeding and malnutrition) are directly related to the health of the nation. Pakistan commercial poultry is an important and significant contributor in livestock share in GDP that has added1809 (000 tons) of meat, and 21, 285 millions eggs in FY 2021 as well as a major source of employment to almost 8 millions throughout the country (GoP, 2021). Producing more eggs and meat by growing more poultry

"Corresponding author: drshah73@yahoo.com can combat the shortage of protein requirement by the cheapest available source of animal protein through filling the gap of protein availability as the poultry have a rapid growth rate and low generation gap as compared to other livestock.

Avian Pathogenic Escherichia coli (E. coli) cause severe economic losses in the animal and poultry industry by increasing morbidity and mortality rate as well as reducing the production of the animals. It causes a variety of infections through pan systemic involvement of various vital systems of the body. Amongst, colibacillosis is associated with respiratory and intestinal infections; it causes extra intestinal disease in humans and mammals. Infections progress to many other organs as salpingitis, peritonitis, cellulitis, perihepatitis, polyserositis, septicemia, and death (Dho-Moulin, 1999; Barnes 2003; Jeong et al., 2012; Awad et al., 2016). 
Various studies on Epidemiological and prevalence of $E$. coli infection described have been reported earlier in calves, pigs, ducks and turkeys. These findings revealed the prevalence of positive strains. These investigators found this infection as the most significant bacterial disease in poultry worldwide (Harel et al., 1991; Dozois et al., 1992, Dozois et al., 1997; Stordeur et al., 2002). E. coli, the predominant organism isolated from number of lesions in various avian studies showed reduced weight gain, poor feed conversion, down grading of carcasses and condemnation at slaughter, infection of soft tissues as well initiating cellulitis particularly in the broiler (Baracho et al., 2006).

Clinically E. coli infection is the most devastating disease that it consequences huge mortality, culling, treatment costs; infected birds show dissemination of infection. Several researchers have revealed purulent inflammation of avian lungs, presence of apoptotic cells. They also found dullness and depression with an elevation of temperature, in appetence, diarrhea, cyanosis, salpingitis and peritonitis in layers, infection of the reproductive tract, perihepatitis, pericarditis, damaged lymphatic organs and immune function.( Barnes, et al., 2008; Horn et al., 2012; Landman et al., 2013; Pors et al., 2014; Sun et al., 2015; Jia et al., 2017). Since, Avian E. coli infections are ubiquitous and widely spread in Pakistan and cause heavy economic losses to the poultry farmers. Thus, this study aimed to determine the prevalence and pathology produced by avian pathogenic Escherichia coli in different age groups of broiler in the surroundings of Karachi, Pakistan.

\section{MATERIALS AND METHODS \\ Prevalence of infection in broiler chicken}

The investigations were carried out to record the prevalence of $E$. coli infections in different age groups of broilers at different commercial poultry farms in surroundings of Karachi, Pakistan. To observe the pathogenesis in different age groups of chicks, 140 commercial broiler poultry farms were visited; the disease was investigated from day first up to the marketing. Total number of farms (140) was divided into seven groups (A, $B, C, D, E, F$ and $G$ ), each group having twenty broiler poultry farms (comprising 1000-7000 chicks). Group-A represents the age group from day 1 to day 7 ( $1^{\text {st }}$ week), from 08 to 14 days in group $B\left(2^{\text {nd }}\right.$ week $)$, from 15 to 21 days in group $C$ ( $3^{\text {rd }}$ week $), 22$ to 28 days in group D $\left(4^{\text {th }}\right.$ week), 29 to 35 days in group E ( $5^{\text {th }}$ week), 36 to
42 days in group $F\left(6^{\text {th }}\right.$ week) and from day 43 up to marketing in group $\mathrm{G}$, respectively.

\section{Gross pathological observations}

During the visits, a postmortem of dead birds was conducted, the lesions observed were recorded and positive samples were collected and preserved in $10 \%$ formol saline solution and brought to the Post Graduate Pathological Laboratory of the Department.

\section{Histopathological observations}

To determine the histopathological changes, collected samples were processed with ascending grades of ethyl alcohol (starting from $30 \%$ to absolute) for dehydration. Then the sample was cleared in xylene and embedded in paraffin wax. After embedding the tissues were cut in $4-5 \mu$ section size. Ribbons were placed in the hot water bath to get rid of the wrinkle formation. These sections were mounted on slides and stained with Hemotoxyline and Eosin. These slides were then examined for histopathological changes.

\section{Media prepared for isolation of $E$. coli}

Commercially available McConkey's agar was prepared by mixing 05 grams of McConkey's agar with $100 \mathrm{ml}$-distilled water in conical flask. A homogenous mixture was obtained by gently mixing and heating on the hot plate. The mixture was cooled at the room temperature, $\mathrm{pH}$ was adjusted at 7.4, (by adding $\mathrm{NaOH}$ and $\mathrm{NaHCO}_{3}$ ), autoclaved at $15 \mathrm{lbs}$. pressure at $121^{\circ} \mathrm{C}$ for 15 minutes, after autoclaving, the medium was cooled at $50^{\circ} \mathrm{C}$ and then $15 \mathrm{ml}$ was distributed into sterilized petri dishes.

\section{Blood agar base}

Commercially available Blood Agar media was used for the culture of $E$. coli. Media consisted Lab-Lemco Powder $10 \mathrm{gms}$, Peptone $10 \mathrm{gms,}$ $\mathrm{NaclO} 5 \mathrm{gms}$, and Agar $15 \mathrm{gms}$. Forty grams of blood agar base medium was dehydrated in 1000 $\mathrm{ml}$ of distilled water and after mixing the $\mathrm{pH}$ of medium was adjusted at 7.3. Then the medium was autoclaved for $15 \mathrm{~mm}$. at $121^{\circ} \mathrm{C}$ under 15 lbs pressure. After cooling at $50^{\circ} \mathrm{C}$ about $10 \%$ fresh defibrinated sheep blood was added and subsequently distributed into petridishes. After solidification the plates were incubated for 24 hrs at $37^{\circ} \mathrm{C}$ for the sterility of the medium. The sterile blood agar plates were used for primary isolation of $E$. coli.

\section{Culture of sample}

The samples from infected yolk and liver with $E$. coli were collected from different chicks and 
cultured by sterilized platinum loop into the McConkey's nutrient agar and blood agar and incubated for 24 hours at $37^{\circ} \mathrm{C}$ for characteristic and morphological observations. The study was conducted at Central Veterinary Research and Diagnostic Laboratory, Tandojam.

\section{RESULTS}

The systematic investigations were carried out to record the prevalence of $E$. coli infections in the boiler at commercial poultry farms in the surroundings of Karachi. The period of studies lasted five months. During the period, 140 commercial poultry broiler farms were visited to confirm the disease.

\section{Prevalence of $E$. coli infections}

During the study period, the prevalence of E. coli infections was recorded at various broiler farms. The highest rate of prevalence was found in group $E(33.2 \%)$, followed by group $G(27.7 \%)$, whereas, the prevalence of $E$. coli infection was observed as $14.6 \%, 13.6 \%, 17.7 \%, 27.5 \%$, and $26.9 \%$ in groups $A, B, C, D$ and $F$ respectively (Table1).

Table 1. Prevalence of $E$. coli in different groups

\begin{tabular}{|l|l|l|l|}
\hline Groups & $\begin{array}{l}\text { Total No. of } \\
\text { birds reared }\end{array}$ & $\begin{array}{l}\text { No. of Sick } \\
\text { Birds (\%) }\end{array}$ & $\begin{array}{l}\text { No. of Positive } \\
\text { Birds (\%) }\end{array}$ \\
\hline $\mathrm{A}\left(1^{\text {st }}\right.$ Week $)$ & 12500 & $996(7.69 \%)$ & $146(14.65)$ \\
\hline $\mathrm{B}\left(2^{\text {nd }}\right.$ Week $)$ & 15000 & $1499(9.99 \%)$ & $204(13.60)$ \\
\hline $\mathrm{C}\left(3^{\text {Id }}\right.$ Week $)$ & 15700 & $1587(10.10 \%)$ & $282(17.76$ \\
\hline $\mathrm{D}\left(4^{\text {th }}\right.$ Week $)$ & 14000 & $1620(11.57 \%)$ & $447(27.59$ \\
\hline $\mathrm{E}\left(5^{\text {tn }}\right.$ Week $)$ & 12000 & $1675(13.95 \%)$ & $557(33.23$ \\
\hline $\mathrm{F}\left(7^{\text {th }}\right.$ Week $)$ & 14600 & $1490(10.20 \%)$ & $401(26.91$ \\
\hline $\mathrm{G}\left(8^{\text {In }}\right.$ Week $)$ & 17000 & $1637(9.62 \%)$ & $454(27.73)$ \\
\hline Grand Total & 100800 & $10504(10.42 \%)$ & $2491(23.71)$ \\
\hline
\end{tabular}

\section{Gross pathology}

Gross pathological lesions varied at different broiler farms comprising the birds of various age groups. The lesions observed in different organs indicated higher infarction of $E$. coli in birds of the $5^{\text {th }}$ week and subsequently decreased in older birds as indicated in (Table 2).

\section{Omphalitis}

The maximum rate of infection was observed in group A with $76.24 \%$ and minimum in group B with $23.76 \%$ whereas, omphalitis was not seen in other groups (Table 3 ). The gross lesions observed were panophthalmitis, unabsorbed yolk, congestion of the small intestine, and necrotic foci in the liver (Figure 3A and 3B).

\section{Colisepticaemia}

The maximum rate of infection $29.63 \%$ was observed in group $\mathrm{E}$ whereas, minimum of $3.11 \%$ in group B while no infection was observed in group A. However, the rate of infection in other groups was as 22.18, 20.18, 18.63 and $6.74 \%$ were seen in group G,D,F and $\mathrm{C}$ respectively (Table 3 ).

The gross pathological lesions about colisepticaemia were observed in certain visceral organs such as the liver, heart, and air sacs. The most common lesions were fibrinous perihepatitis, hepatomegaly with pale-colored necrotic foci, fibrinous pericarditis along clotted blood present in the heart, the air sacs were found inflamed due to presence of caseous exudates.

\section{Colibacillosis}

The maximum rate of infection was observed in group $G$ as $28.55 \%$ whereas, the minimum was $0.075 \%$ in group A. However, the rate of infection was $26.70,19.20,16.11,5.99$, and 3.35 in group $E, D, F$, and $B$ respectively as shown in (Table 3).

Table 2. Specific lesions were observed in various age groups infected with $E$. coli

\begin{tabular}{|c|c|c|c|c|c|c|c|c|c|}
\hline \multirow[t]{2}{*}{ Form of Infection } & \multirow[t]{2}{*}{ Specific Lesions observed } & \multicolumn{7}{|c|}{ Groups } & \multirow[t]{2}{*}{ Total } \\
\hline & & $\mathbf{A}$ & B & C & D & $\mathrm{E}$ & $\mathbf{F}$ & $\mathbf{G}$ & \\
\hline $\begin{array}{l}\text { 1.Obphalitis and its } \\
\text { forms } 1.1 \text { Mushy }\end{array}$ & $\begin{array}{l}\text { Unabsorbed yolk, congested blood } \\
\text { vessels, and panophthalmitis }\end{array}$ & 125 & 15 & - & - & - & - & - & 140 \\
\hline 1.2 Naval ill & Emaciation & 13 & 28 & - & - & - & - & - & 41 \\
\hline \multirow[t]{3}{*}{ 2.Colisepticaemia } & 2.1 Fibrinous perihepatitis & - & - & 38 & 112 & 291 & 139 & 168 & 748 \\
\hline & 2.2 Fibrinous Pericarditis & - & - & 33 & 72 & 68 & 74 & 88 & 335 \\
\hline & 2.3 Air Sacculitis & - & 62 & 63 & 217 & 230 & 148 & 185 & 905 \\
\hline \multirow[t]{7}{*}{ 3. Colibacillosis } & 3.1 Enteritis & 5 & 33 & 59 & 225 & 323 & 202 & 294 & 1141 \\
\hline & 3.2 Necrotic foci on liver & - & 39 & 71 & 228 & 192 & 173 & 231 & 934 \\
\hline & 3.3 Hemorrhages on heart & - & 20 & 23 & 139 & 179 & 43 & 83 & 487 \\
\hline & 3.4 Tracheitis & - & 50 & 73 & 207 & 297 & 171 & 327 & 1125 \\
\hline & 3.5 Nephritis & - & 50 & 74 & 160 & 280 & 185 & 331 & 1080 \\
\hline & 3.6 Osteodystrophy & - & - & 35 & 161 & 233 & 155 & 332 & 916 \\
\hline & 3.7 Petechiation of Gizzard & - & 30 & 62 & 152 & 265 & 138 & 293 & 940 \\
\hline \multirow{6}{*}{$\begin{array}{l}\text { 4. E. coli and other } \\
\text { infections }\end{array}$} & 4.1 H.P.S & - & 51 & 3 & 55 & 223 & 202 & 162 & 696 \\
\hline & 4.2 N.D. & - & - & 60 & 80 & - & 49 & - & 189 \\
\hline & 4.3 I.B.D. & - & - & - & 106 & 120 & 20 & 80 & 326 \\
\hline & 4.4 Coccidiosis & - & - & 105 & 50 & 32 & 35 & 100 & 322 \\
\hline & 4.5 Water belly (Ascites) & - & - & 13 & - & - & 27 & 72 & 112 \\
\hline & 4.6 C.R.D & 3 & 70 & 92 & 276 & 323 & 194 & 296 & 1254 \\
\hline \multicolumn{2}{|l|}{ Grant Total } & 146 & 448 & 804 & 2240 & 3056 & 1955 & 3042 & 11691 \\
\hline
\end{tabular}

Group A represents $1^{\text {st }}$ week, B $2^{\text {nd }}$ Week, $C 3^{\text {rd }}$ Week, D $4^{\text {th }}$ Week, E $5^{\text {th }}$ Week, $\mathrm{F} 6^{\text {th }}$ Week, and $\mathrm{G} 7^{\text {th }}$ up to marketing. 
Pak. J. Agri., Agril. Engg., Vet. Sci., 2021, 37 (2)

Table 3. Rate of infections observed in various forms of $E$. coli in different age groups

\begin{tabular}{|c|c|c|c|c|c|c|c|c|c|c|c|c|c|c|c|c|}
\hline \multirow{2}{*}{$\begin{array}{l}\text { Form of } \\
\text { Infection } \\
\text { (Omphalitis and } \\
\text { its form) }\end{array}$} & \multirow{2}{*}{\begin{tabular}{|l} 
Specific \\
Lesions \\
observed
\end{tabular}} & \multicolumn{14}{|c|}{ Groups with Percentage } & \multirow{2}{*}{$\begin{array}{l}\text { No. of birds } \\
\text { examined }\end{array}$} \\
\hline & & A & $\%$ & B & $\%$ & C & $\%$ & D & $\%$ & $E$ & $\%$ & $F$ & $\%$ & G & $\%$ & \\
\hline $\begin{array}{l}\text { Types } \\
\text { Mushy }\end{array}$ & \begin{tabular}{|l|} 
Unabsorbed \\
yolk, \\
congested \\
blood \\
vessels and \\
panophthalmitis \\
\end{tabular} & 125 & \multirow[t]{2}{*}{76.24} & 15 & \multirow[t]{2}{*}{23.76} & - & \multirow[t]{2}{*}{-} & - & \multirow[t]{2}{*}{-} & - & \multirow[t]{2}{*}{-} & - & \multirow[t]{2}{*}{-} & - & & \multirow[t]{2}{*}{181} \\
\hline Naval ill infection & Emaciation & 13 & & 28 & & - & & - & & - & & - & & G & & \\
\hline \multirow[t]{3}{*}{ Colisepticaemia } & $\begin{array}{l}\text { 2.1 Fibrinous } \\
\text { Perihepatitis }\end{array}$ & - & \multirow[t]{3}{*}{-} & - & \multirow[t]{3}{*}{3.11} & 38 & \multirow[t]{3}{*}{6.74} & 112 & \multirow[t]{3}{*}{20.18} & 291 & \multirow[t]{3}{*}{29.63} & 139 & \multirow[t]{3}{*}{18.63} & 168 & \multirow[t]{3}{*}{22.18} & \multirow[t]{3}{*}{1988} \\
\hline & \begin{tabular}{|l|}
2.2 Fibrinous \\
Pericarditis
\end{tabular} & - & & - & & 33 & & 72 & & 68 & & 74 & & 88 & & \\
\hline & $\begin{array}{l}2.3 \text { Air } \\
\text { Sacculitis }\end{array}$ & - & & 62 & & 63 & & 217 & & 230 & & 148 & & \begin{tabular}{|l|}
185 \\
\end{tabular} & & \\
\hline \multirow[t]{7}{*}{ Colibacillosis } & 3.1 Enteritis & 5 & \multirow[t]{7}{*}{0.075} & 33 & \multirow[t]{7}{*}{3.35} & 59 & \multirow[t]{7}{*}{5.99} & 225 & \multirow[t]{7}{*}{19.20} & 323 & \multirow[t]{7}{*}{26.70} & 202 & \multirow[t]{7}{*}{16.11} & 294 & \multirow[t]{7}{*}{28.55} & \multirow[t]{7}{*}{6623} \\
\hline & $\begin{array}{l}\text { 3.2 Necrotic } \\
\text { foci on liver }\end{array}$ & 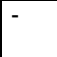 & & 39 & & 71 & & 228 & & 192 & & 173 & & 231 & & \\
\hline & \begin{tabular}{|l|}
3.3 \\
Hemorrhages \\
on heart
\end{tabular} & - & & 20 & & 23 & & 139 & & 179 & & 43 & & 83 & & \\
\hline & 3.4 Tracheitis & - & & 50 & & 73 & & 207 & & 297 & & 171 & & 327 & & \\
\hline & 3.5 Nephritis & - & & 50 & & 74 & & 160 & & 280 & & 185 & & 331 & & \\
\hline & \begin{tabular}{|l|}
3.6 \\
Osteodystrophy
\end{tabular} & - & & - & & 35 & & 161 & & 233 & & 155 & & 332 & & \\
\hline & \begin{tabular}{|l|}
3.7 \\
Petechiation of \\
Gizzard \\
\end{tabular} & - & & 30 & & 62 & & 152 & & 265 & & 138 & & 293 & & \\
\hline
\end{tabular}

Group A represents $1^{\text {st }}$ week, B $2^{\text {nd }}$ Week, C $3^{\text {rd }}$ Week, D $4^{\text {th }}$ Week, E $5^{\text {th }}$ Week, $\mathrm{F} 6^{\text {th }}$ Week, and $\mathrm{G} 7^{\text {th }}$ up to marketing.
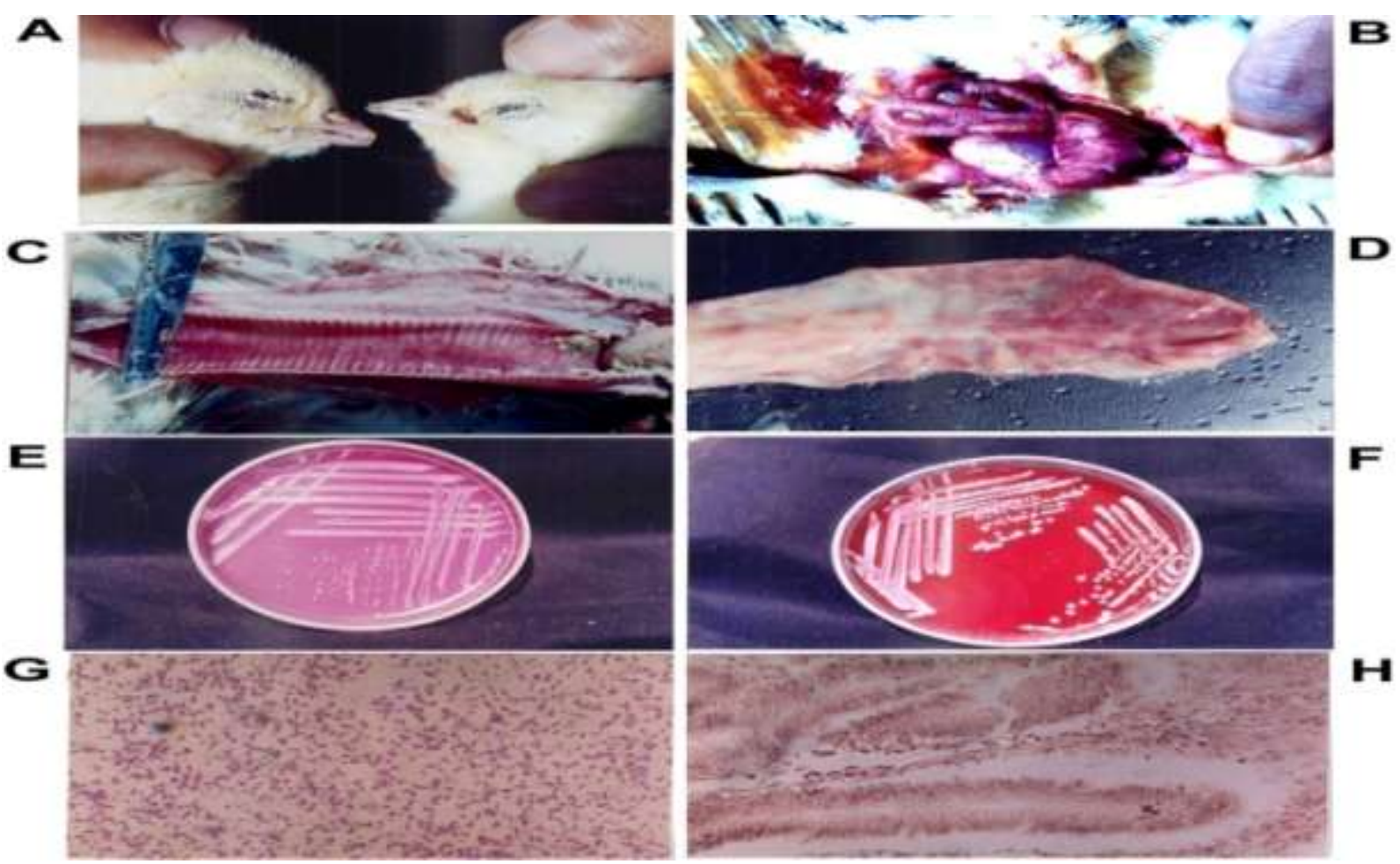

Figure 3. Various pathological conditions caused by E. coli in broiler chicken. Figure 3A shows panophthalmitis in day-old chick. Figure $3 \mathrm{~B}$ shows classical postmortem signs for omphalitis due to $E$. coli. Figure $3 \mathrm{C}$ and $\mathrm{D}$, Shows hemorrhagic tracheitis and enteritis respectively, severe hemorrhages can be observed. Figure $3 \mathrm{E}$ and $\mathrm{F}$, represent cultural characteristics of $E$. coli in the broiler on blood agar and McConkey's agar. Figure 3G represents the morphology of Escherichia coli after successful culture and Figure $3 \mathrm{H}$ shows disruption of villus due to $E$. coli in a histological study ( $\mathrm{H}$ and $\mathrm{E}$, magnification $40 \mathrm{X}$ ). 
The gross pathological lesions varied in different visceral organs in the case of colibacillosis which included necrotic foci and hemorrhages in the liver, hemorrhagic patches in both the heart and gizzard. The kidney was also inflamed and in some cases showed necrotic lesions in the peripheral region. Gall bladder was enlarged and distended in some of the cases, whereas in some cases, the lesions of C.R.D were associated (Table 3) with hemorrhagic tracheitis (Figure $3 \mathrm{C}$ ), hemorrhagic enteritis (Figure 3D) along with the lesions of mixed infections (Table 3). In general, colibacillosis with $56.65 \%$ was noticed as maximum, whereas, colisepticaemia with $17 \%$ was observed as a minimum. While other associated diseases with $24.80 \%$ and omphalitis with $1.55 \%$ were $2^{\text {nd }}$ and $3^{\text {rd }}$ week respectively (Table 4).

Table 4. Rate of infection in various types of $E$. coli along with mixed infection

\begin{tabular}{|l|l|l|}
\hline Disease & $\begin{array}{l}\text { No. of Lesions } \\
\text { observed }\end{array}$ & Percentage \\
\hline Omphalitis & 181 & 1.55 \\
\hline Colisepticaemia & 1,988 & 17.00 \\
\hline Colibacillosis & 6,623 & 56.65 \\
\hline $\begin{array}{l}\text { Escherichia coli and } \\
\text { other infections }\end{array}$ & 2,899 & 24.80 \\
\hline Grand Total & 11,691 & 100 \\
\hline
\end{tabular}

\section{Histopathological observations}

There was no any histopathological lesion observed in serosa, musclaris externa and submucosa but the lesions in the mucosa revealed loss of epithelial tissue along with desquamation (Figure $3 \mathrm{H}$ ), leukocytic infiltration of necrotic foci were found in liver, heart, and kidney.

\section{Cultural and morphological characteristics of Escherichia coli}

The morphological study was conducted by culturing the specimens on different media revealed either singly or paired colonies with pinkish, small, circular, smooth, translucent, and convex colonies on McConkey's agar and greywhite (Figure 3E), glistening circular with convex colonies on blood agar (Figure 3F).

\section{DISCUSSION}

One hundred forty commercial broiler farms were surveyed to record the prevalence of $E$. coli infections in the surroundings of Karachi Pakistan. The studies were carried out to record the infection of $E$. coli in different age groups of birds from day one up to the marketing. The infection rate was recorded as $14.6 \%, 13.6 \%$, $17.7 \%, 27.5 \%, 33.2 \%, 26.9 \%$ and $27.7 \%$ in group $A, B, C, D, E, F$ and $G$, respectively.

The gross pathological lesions varied in different organs of various age groups. Omphalitis was observed as $76.2 \%$ in group A and $23.7 \%$ in group. Colisepticaemia as $3.1 \%$, $6.7 \%, 21.1 \%, 18.1 \%$, and $22.1 \%$ in birds of group $\mathrm{B}, \mathrm{C}, \mathrm{D}, \mathrm{E}, \mathrm{F}$, and $\mathrm{G}$, while in group $\mathrm{A}$, Colisepticaemia was not observed. Whereas colibacillosis was found in all groups as $0.07 \%$ in $\mathrm{A}, 3.3 \%$ in $\mathrm{B}, 5.9 \%$ in $\mathrm{C}, 19.2 \%$, in $\mathrm{D}, 26.7 \%$ in $E, 16.1 \%$ in $F$, and $28.5 \%$ in $G$ groups of birds. The specific macroscopic lesions observed in the case of omphalitis included unabsorbed yolk material (sac) congested intestinal mucosa along with panophthalmitis whereas in the case of colisepticaemia there were fibrinous pericarditis, perihepatitis, and airsaculitis. While, in the case of colibacillosis, gross lesions observed were petechiation in the heart, kidney and gizzard besides enteritis tracheitis and necrotic foci in liver and caseous exudate in air sacs. Histopathological lesions revealed congestion, degenerative changes in the intestine, and leukocytic infiltration in liver, heart and kidneys with sometimes necrotic foci especially in the heart. Based on the observed lesions, the form of colibacillosis in the current study could be a hepatic form of colibacillosis. Histopathological lesions in the intestine, lungs and liver, were also identified by previous studies (Gosh et al., 2006; Talha et al., 2001; Riaz et al., 2016).

Colibacillosis is a contagious disease of chicken caused by E. coli (Barnes et al., 2008), it is classified as one of the major causes of an increase in morbidity and mortality rate in commercial farms, consequently leading to large economic losses to the poultry farming through its association with other diversified diseases, as a primary or secondary pathogen (McPeake et al., 2005; Tonu et al., 2012; Mbanga and Nyararai 2015).

Avian colibacillosis noticed to be a major infectious disease in all age birds, and has various local and systemic symptoms. The current study agrees with previous findings, in our finding various lesions were found in the liver, intestine and lungs. Died chicks showed postmortem signs for omphalitis intestinal hemorrhagic with tracheitis and enteritis respectively with severe hemorrhages observed. The poor flock performance and managements practices correlated with increased early 
mortality rates in broiler forms, Histopathological observations in the present study had similarities to observations earlier (Barnes et al., 2008; Riaz et al., 2016).

In conclusion, the results of this study confirm the prevalence of avian pathogenic $E$. coli in the field, based on morphological and histological lesions and cultural findings. The economic and poultry health burden of this disease emphasizes the effective surveillance and control measures to reduce economic losses inflicted to the farmer due to this hazard.

\section{Novelty statement}

We report that no such data have been published earlier and this is first ever report on natural infection of Avian Escherichia coli in Pakistan. This data will prove to be complete data on Avian Escherichia coli in meat-type chicken from day 1 , upto marketing.

\section{AUTHOR'S CONTRIBUTION}

Q. A. Shah: Executed the experiment, data collection, analysis and overall manuscript writeup

N. M. Soomro: Helped in the development of experiment and generation of the data

J. M. Shah: Provided technical support in data and sample collection from the study area

M. A. Hussain: Helped in data collection

S. F. Sayed: Helped in data collection and culture of E. coli (Prevalence)

\section{CONFLICT OF INTEREST}

There is conflict of interest among authors.

\section{REFERENCES}

Awad, A., N. Arafat and M. Elhadidy. 2016. Genetic elements associated with antimicrobial resistance among avian pathogenic Escherichia coli. Annals of Clinical Microbiology and Antimicrobials, 15 (1): 1-8.

Baracho, M. S., G. A. Camargo, A. M. C. Lima, J. F. Mentem, D. J. Moura, J. Moreira and I. A. Nääs. 2006. Variables impacting poultry meat quality from production to preslaughter: A review. Revista Brasileira de Ciência Avícola, 8 (4): 201-212.

Barnes, H. J., J. P. Vaillancourt, W. B. Gross and Y. M. Saif. 2003. Colibacillosis. Diseases of Poultry. $11^{\text {th }} \mathrm{Ed}$. Ames lowa State Press, pp. 631-656.

Barnes, H. J., L. K. Nolan, J. P. Vaillancourt, Y. M. Saif, A. M. Fadley, J. R. Glisson, L. R. McDougald, L. K. Nolan and D. Swayne.
2008. Colibacillosis (Eds.). Diseases of Poultry. lowa State Press, Ames, pp. 691732.

Dho-Moulin, M. and J. M. Fairbrother. 1999. Avian pathogenic Escherichia coli (APEC). Veterinary Research, 30 (2): 299-316.

Dozois, C. M., J. M. Fairbrother, J. O. S. E. E. Harel and M. A. R. C. Bosse. 1992. Papand pil-related DNA sequences and other virulence determinants associated with Escherichia coli isolated from septicemic chickens and turkeys. Infection and Immunity, 60 (7): 2648-2656.

Dozois, C. M., S. Clément, C. Desautels, E. Oswald and J. M. Fairbrother. 1997. Expression of $\mathrm{P}, \mathrm{S}$, and $\mathrm{F} 1 \mathrm{C}$ adhesions by Cytotoxic necrotizing factor 1-producing Escherichia coli from septicemic and diarrheic pigs. FEMS Microbiology Letters, 152 (2): 307-312.

Ghosh, R. C., S. D. Hirpurkar and P. R. Suryawanshi. 2006. Concurrent colibacillosis and infectious bursal disease in broiler chicks. Indian Veterinary Journal, 83 (9): 1019-1020.

GoP, 2021. Economic Survey of Pakistan (Ministry of Finance, Government of Pakistan).

Harel, F., Daigle, S. Maiti, C. Desautels, A. Labigne and J. M. Fairbrother. 1991. Occurrence of pap-, sfa-, and afa-related sequences among F165-positive Escherichia coli from diseased animals, FEMS Microbiology Letters, 82 (2): 177-182.

Horn, F., A. M. R. Corrêa, N. L. Barbieri, S. Glodde, K. D. Weyrauch and B. Kaspers. 2012. Infections with avian pathogenic and Fecal Escherichia coli strains display similar lung histopathology and macrophage apoptosis. PLoS one, 7 (7): e41031.

Jeong, Y. W., T. E. Kim, J. H. Kim and H. J. Kwon. 2012. Pathotyping avian pathogenic Escherichia coli strains in Korea. Journal of Veterinary Science, 13 (2): 145-152.

Jia, X., Q. Nie, X. Zhang, L. K. Nolan and S. J. Lamont. 2017. Novel micro RNA involved in host response to avian pathogenic Escherichia coli identified by deep sequencing and integration analysis. Infection and Immunity, 85 (1): e00688-16.

Landman, W. J. M., A. Heuvelink and J. H. H. Van Eck. 2013. Reproduction of the Escherichia coli peritonitis syndrome in laying hens. Avian Pathology, 42 (2): 157-162. 
Mbanga, J. and Y. O. Nyararai. 2015. Virulence gene profiles of avian pathogenic Escherichia coli isolated from chickens with coli bacillosis in Bulawayo, Zimbabwe. Onderstepoort Journal of Veterinary Research, 82 (1): 1-8.

McPeake, S. J. W., J. A. Smyth and H. J. Ball. 2005. Characterization of avian pathogenic Escherichia coli (APEC) associated with Coli septicaemia compared to faecal isolates from healthy birds. Veterinary Microbiology, 110 (3-4): 245-253.

Pors, S. E., R. H. Olsen and J. P. Christensen. 2014. Variations in virulence of avian pathogenic Escherichia coli demonstrated by the use of a new in vivo infection model. Veterinary Microbiology, 170 (3-4): 368-374.

Riaz, A. M., A. Aslam, M. Rehman and T. Yaqub. 2016. Pathological Investigation and Molecular Detection of Avian Pathogenic E. coli Serogroups in Broiler Birds. Journal Veterinary Science Technology, 7: 373.
Stordeur, P., D. Marlier and J. Blanco. 2002. Examination of Escherichia coli from poultry for selected adhesin genes important in disease caused by mammalian pathogenic Escherichia coli. Veterinary Microbiology, 84 (3): 231-241.

Sun, H., P. Liu, L. K. Nolan and S. J. Lamont. 2015. Avian pathogenic Escherichia coli (APEC) infection alters bone marrow transcriptome in chickens. BMC Genomics, $16(1): 1-15$.

Talha, A. F. S. M., M. M. Hossain, E. H. Chowdhury, A. S. M. Bari, M. R. Islam and P. M. Das. 2001 Poultry diseases occurring in Mymensingh district of Bangladesh. The Bangladesh Veterinarian, 18 (1): 20-23.

Tonu, N. S., M. A. Sufian, S. Sarker, M. M. Kamal, M. H. Rahman and M. M. Hossain. 2012. Pathological study on colibacillosis in chickens and detection of Escherichia coli by PCR. Bangladesh Journal of Veterinary Medicine, 9 (1): 17-25.

(Received: September 29, 2021; Accepted: October 28, 2021) 